\title{
Research on the Mixed Teaching Mode under the Information Condition-Taking the Teaching of Wechat Public Platform of Sports Skating Club in Qingdao Vocational and Technical College as an Example
}

\author{
Jingrui Cheng \\ (Basic Teaching Department in Qingdao Vocational and Technical College Jingrui Cheng \\ Qingdao, Shandong 266555) \\ Lecturer, Daqing, Heilongjiang, Undergraduate, Lecturer, Research direction: Physical \\ education and training
}

Keywords: Information; Mixed model; Sports club; Roller skating

\begin{abstract}
With the rapid development of information technology, it is imminent to change the traditional single physical education model. The mixed teaching combines the advantages of traditional teaching with the advantages of E-Learning, and it combines with practical disciplines such as sports which can promote the reform of physical education teaching model, and this point has extremely important significance.
\end{abstract}

\section{The Background of the Problem}

The mixed teaching method is a new teaching method that has been proposed by the United States in recent years. It is a method that integrates traditional face-to-face classroom instruction learning methods with digital and networked distance education methods. The mixed teaching was first proposed and defined by Professor Kekang He in China, and he believes that the so-called mixed teaching combines the advantages of traditional teaching with the advantages of E-Learning, and the teaching process is the combination of teacher supervision and student learning, and students actively participate in teaching. In recent years, domestic and foreign experts and scholars have carried out active researches around mixed teaching, and the researches are mainly focusing on theories, resource construction, learning system design and empirical research. This has provided new ideas and directions for teaching reform. At present, the mixed teaching model has relatively many achievements in combination with theoretical courses, but it has few results in conjunction with practical hands-on practice such as sports. Physical education is an important part of school sports, and it is of great significance to the development of students' lifelong physical habits. The content of physical education curriculum is mostly practice-based, and the teaching process is usually the teacher teaching and demonstrating knowledge points, and the students take targeted practice, then the teacher corrects mistakes according to practice, and the students improve and gradually learn technical movements. This type of teaching organization is relatively simple, but the teacher has difficult to have a specific consideration of all students in the class, so the traditional teaching lacks of personalized guidance based on the specific circumstances of different students.

As far as the Qingdao Vocational and Technical College is concerned, with the rapid development of the campus network and the increasing popularity of student mobile terminals, these objective conditions have laid a solid foundation for the development of a new teaching model -mixed teaching. The physical education teaching staff relies on the college-level self-produced stereo information teaching materials to expand the ways with APP "Smart Vocational Education", "Baidu Biography", "Mobile WeChat", "National College Teachers Online Training Center" and "Tencent Classroom". And this takes improving students' interest in learning sports as the point of 
departure, and it combines with the teaching methods of NCEE's innovation and entrepreneurship education and training promoted by the Youth Vocational College which continuously optimizes the teaching mode of the PE course and focuses on the research of the mixed teaching mode that has achieved a certain degree of effectiveness.

\section{Specific implementation Process}

\section{Establishment of Learning Resources}

This study takes the example of roller skating course teaching in the third semester of the Qingdao Vocational and Technical College as an example to illustrate the implementation process of blended teaching. In view of the fact that students have a certain foundation for the content of the course, before the whole course is opened, the diagnostic evaluation method is used to understand the students' needs and problems in the course content. Questionnaires are distributed after the class to allow students to actively think about the feasibility of teaching content. The "NCEE" training red and green voting method is adopted, that means the opinions are quickly collected through the support of the red ticket or green ticket method so that teachers can fully solicit opinions of students. On the basis of this, targeted adjustments are made to the content of the classes, and targeted groupings are conducted according to the student's situation, and the leader responsibility system is established. The teaching content is regularly evaluated against the learning content to determine the students' preparatory knowledge of the teaching content.

Table 1 Self-evaluation of course content of club roller skating course

\begin{tabular}{|l|l|l|l|}
\hline \multirow{2}{*}{ Comment content } & \multicolumn{2}{|c|}{ Select content } \\
\cline { 2 - 4 } & Need & $\begin{array}{c}\text { Don't } \\
\text { need }\end{array}$ & Uncertain \\
\hline $\begin{array}{l}\text { Learning about roller skating basic stations before and after the } \\
\text { fall }\end{array}$ & & & \\
\hline $\begin{array}{l}\text { Understanding and mastering the basic content and practice of } \\
\text { the skating referee law }\end{array}$ & & & \\
\hline $\begin{array}{l}\text { Understanding and mastering the practice of balancing one } \\
\text { foot and two feet }\end{array}$ & & & \\
\hline $\begin{array}{l}\text { Understanding flat-edged grounding, three-variable-blade } \\
\text { grounding and double buckle arc stopping technology }\end{array}$ & & \\
\hline $\begin{array}{l}\text { Understanding the continuous operation of technology and } \\
\text { technical methods }\end{array}$ & & \\
\hline Understanding and mastering the way of arc-sliding legs & & & \\
\hline $\begin{array}{l}\text { Learn basic fancy stud ways(such as snake, fish, backward } \\
\text { slalom by both feet) }\end{array}$ & & & \\
\hline
\end{tabular}

Note: Please draw $" \sqrt{ } "$ in the corresponding column.

After the opinions are collected, the classroom teacher prepares the corresponding lecture content or video resources according to the student's needs. At the same time, the teacher can grasp the situation according to the students' preparatory movements and prepare lessons in a targeted way to meet the individualized learning needs as much as possible.

\section{Implementation Process}

\section{Before Class}

Before the class, the teacher publishes the relevant teaching resources according to the established schedule of the course and guides the students to carry out relevant studies appropriately to lay the foundation for further personalized teaching after class. Relying mainly on the advantages of organizations, the WeChat public number of "Qingdao Vocational and Technical College Fengying Roller Skating Club"was established to release resources. Most of the students participating in the roller skating club come from the "Fengying Roller Skating Club". To 
strengthen the guidance to the students, the club organized the WeChat Group and the public number of "Qingdao Vocational and Technical College Fengying Roller Skating Club" to facilitate communication between students and students and students and teachers. According to the requirements of teaching content, instructors regularly publish lists of teaching tasks or guides which mainly include action videos to be learned (videos from demonstrations of students and teachers during course teaching and students of our school participating in various types of competitions) and mutual evaluation content and so on for students to learn from each other reference, and upload content has no time constraints that means students can watch repeatedly. Teaching videos are from around which are vivid and live, and the force of the model is endless, and it plays a good incentive for students. At the same time, in order to improve the thinking and hands-on ability of students in higher vocational colleges, students are also provided with opinions collection of roller skating equipment and improvement plan design tables before class to facilitate students to find problems during the use of equipment and facilitate the further improvement and research of sports equipment.

Table 2 Mutual review of club skating course groups' study

\begin{tabular}{|c|c|c|c|}
\hline Name & $\begin{array}{c}\text { Learning } \\
\text { action name }\end{array}$ & \multicolumn{1}{|c|}{ Situation of mastery } & Point \\
\hline & $\begin{array}{l}\text { Master } \square \text { Master a little } \square \text { can not } \\
\text { master } \square\end{array}$ & \\
\hline
\end{tabular}

Note: Please draw $" \sqrt{ } "$ in the corresponding column.

Table 3 Improvement opinion for roller skating sports equipment

\begin{tabular}{|l|l|l|l|l|}
\hline $\begin{array}{l}\text { Defect location } \\
\text { name }\end{array}$ & $\begin{array}{l}\text { Description } \\
\text { of existence } \\
\text { problem }\end{array}$ & $\begin{array}{l}\text { Suggestions } \\
\text { for } \\
\text { improvemen } \\
\mathrm{t}\end{array}$ & $\begin{array}{l}\text { Opinion } \\
\text { reporter }\end{array}$ & Get points \\
\hline & & & & \\
\hline
\end{tabular}

Note: Please fill in the corresponding column.

\section{In Class}

Using "smart data bracelet" software to monitor the amount of exercise in class. Traditional physical education is divided into three parts: preparation, basic and the end. In the warm-up preparation part, it is usually measured by several laps, sweating and so on. Most of these standards remain in appearance and lack accurate measurement data. In the mixed teaching process, the "smart data bracelet" takes data as a measure which includes the number of steps taken during a given period of time, calorie consumption and heartbeat data. As a measure, teachers do not need to participate in the entire process, and only need to check the related motion data. The teacher's role is changed from the original monitor to the examiner. At the same time, the accumulated data can be ranked in the corresponding software (for example: Joyruan) for class accumulation data to encourage regular participation in students.
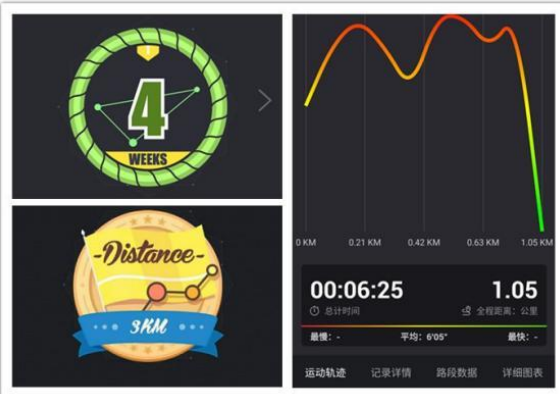

Figure 1. Motion data generated by software monitoring during the course of the course 
In the classroom, the teacher reversed the teaching content according to the content before the class. The teaching transitioned transfers from the main part of the lecture to the "analysis of the difficult points" and "answer questions". The teachers' knowledge points were transferred to the skills and the teachers helped the students to solve the preview process. Teachers help students to solve the technical movements that occur during the preview process in order to achieve full learning of technical movements.

Table 4 Evaluation of student's performance

\begin{tabular}{|c|c|c|c|c|c|c|c|c|c|c|}
\hline \multicolumn{2}{|c|}{ Name of student } & 1 & 2 & 3 & 4 & 5 & 6 & 7 & 8 & 分数 \\
\hline \multirow{3}{*}{ Attitude } & Action preview & & & & & & & & & \\
\hline & Mission completion & & & & & & & & & \\
\hline & $\begin{array}{l}\text { Exercise degree in } \\
\text { class }\end{array}$ & & & & & & & & & \\
\hline \multirow{3}{*}{$\begin{array}{l}\text { performan } \\
\text { ce }\end{array}$} & Assist in practice & & & & & & & & & \\
\hline & $\begin{array}{l}\text { Participating in this } \\
\text { group in exercises }\end{array}$ & & & & & & & & & \\
\hline & $\begin{array}{l}\text { Other activity } \\
\text { participation }\end{array}$ & & & & & & & & & \\
\hline
\end{tabular}

\section{After Class}

Supplementary of teaching resources. In order to make mixed teaching work better, WeChat public account resources alone are far from enough. In addition to using their own resources, they can also draw on more abundant resources such as "Baidu Class", "Tencent Class" and other mobile platforms, and when these resources are used, they need to pay a certain fee.

However, the curriculum resources are relatively systematic and generally consist of a series of micro-classes. These will inevitably enrich the teaching content and expand the horizons of learners. At the same time, we can also use the two-dimensional codes of our school's own three-dimensional digital textbooks to conduct video resource learning (Corresponding action two-dimensional code video is distributed in various chapters). It is convenient and quick. For complex actions, it can also $\log$ on the "Smart Vocational Education" mobile APP platform that our school cooperates with to watch quality award-winning works. These are all beneficial to mixed teaching.

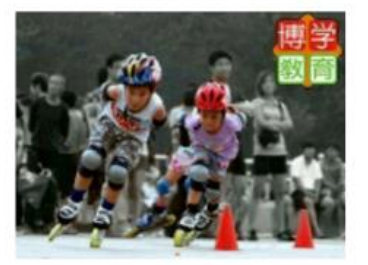

\section{轮滑完整教程}

\section{2次学习}

\section{$¥ 49.00$}

Figure 2. Baidu class video resources

\section{Conclusion}

This research is based on the WeChat public platform and mixes information resources with the environment, learning methods and evaluation methods to break the traditional classroom boundaries and extend classroom teaching. Making preparation before class, taking exercises and instruction in class and making promotion after-class are taken as a total learning process. This kind of mixed teaching aims to cultivate students' conscious learning and improve ubiquitous learning ability. At the same time, for the instructors, they are further relieved from the tedious teaching process, and the transition from a lecturer to a mentor meets the students' individual needs for technical movements as much as possible. This new mode will surely promote physical education, and the reform will develop in depth. 


\section{Acknowlegent}

Fund Project: The 2017 College Education Reform Project of Qingdao Vocational and Technical College: Research on the Mixed Teaching Mode under the Information Condition-Taking the Teaching of Wechat Public Platform of Sports Skating Club in Qingdao Vocational and Technical College as an Example (Item Number:JG201727)

\section{Reference}

[1] Puhua Li.Exploration of MOOC mixed learning in various agent perspective[J].Higher Education Management.2016,(10):35

[2] Zhen Huang. Mixed teaching practice based on MOOC platform[J].Computer age.2016,(2):27 